\title{
Ecology of the City and the Role of Tourism in the Formation of Living Space (on the Example of Urban Ecosystems of the Cities of Kryvyi Rih and Uman)
}

\author{
Serhiy Sonko ${ }^{1 *}$, Olena Lakomova ${ }^{2}$, Daria Shiyan ${ }^{2}$, Tetyana Karpenko², and Yulia Kosenko ${ }^{1}$ \\ ${ }^{1}$ Uman National University of Horticulture, 1, Institutional Str., Uman, 20300, Ukraine \\ ${ }^{2}$ Kryvyi Rih State Pedagogical University, 54, Gagarina Ave., Kryvyi Rih, 50086, Ukraine
}

\begin{abstract}
Despite the significant success of the human population in the development of the planet's resources, man will most likely never be able to completely get rid of dependence on the material and energy mechanisms of the biosphere. The clearest proof of this is the existence of urban ecosystems, within which human living space is formed. However, there is no consensus among researchers on the participation of social and natural components in the formation of urban ecosystems. Moreover, there is no clear answer to the question of how and through what mechanisms the space of human life is formed in modern cities. The article analyzes the ontological affiliation of the category "living space". Numerous aspects of the formation of modern living space have been studied on the specific examples of urban ecosystems of Kryvyi Rih and Uman. In particular, sample surveys of residents of these cities were conducted, based on the results of which conclusions are made about the quality of living space. Tourist activity and tourist resources are considered by the authors as a field of harmonization of human-environment relations in modern conditions of formation of living space.
\end{abstract}

\section{Introduction}

Nowadays, the study of human living space and the category of "living space" is becoming increasingly important from the standpoint of the conceptual and categorical apparatus of many sciences. In many ways, "fitting" for the space of life determines a person's selfidentification, which is extremely important in today's stressful urban environment.

It is logical that the deep foundations of the idea of living space are rooted in the foundations of such basic sciences as ecology, sociology and psychology.

How far has man departed from other biological species in the perception of environmental factors and reactions to them? This is an eternal question of human ecology, projected on urban ecology and still remains unanswered.

What types of people relations with the space (more broadly, the environment) of life are most important and critical to their life?

These are the questions that need to be answered, especially against the background of the aggravation of such problems of human civilization as pandemics, terrorism, overpopulation and others.

Are there any real ways out of these crisis trends, or at least a reduction in their impact? Probably, these are the questions that will be very relevant in the near future.

Thus, from the point of view of science, the category of "living space" grows into an independent interdisciplinary scientific problem, the solution of which, according to V.I. Vernadsky, should be directed to the efforts of many sciences. The formalization of this problem through the methodological and conceptualcategorical apparatus of various sciences formulates the purpose of our study.

Trying to explore the multifaceted categories of living space, the authors set themselves the following tasks:

1. Determine the ontological affiliation of the category "living space".

2. Investigate the degree of influence of each dimension of this category on a person at different spatial levels.

3. Investigate various aspects of the use of living space in the urban ecosystems of Kryvyi Rih and Uman.

4. Investigate the role of the main branches of urban economy that form and use the living space of Kryvyi Rih and Uman.

The object of research is the urban environment of the cities of Kryvyi Rih and Uman.

The subject of research is the space of human life, which is formed under the influence of environmental, social and psychological factors.

Recently, this category has been interpreted mostly from the standpoint of racial theory, according to which a privileged nation objectively looks for expanding its living space. The founding father of the theory is Friedrich Ratzel, who set it out in "Political Geography" in 1897 [1]. Theory of the "continental bloc" (BerlinMoscow-Tokyo axis) was eventually transformed by the Third Reich into the concept of "living space in the East." Our ideas about the modern space of life are

\footnotetext{
* Corresponding author: sp.sonko@gmail.com
} 
incomparable and very far from the above meaning of the concept.

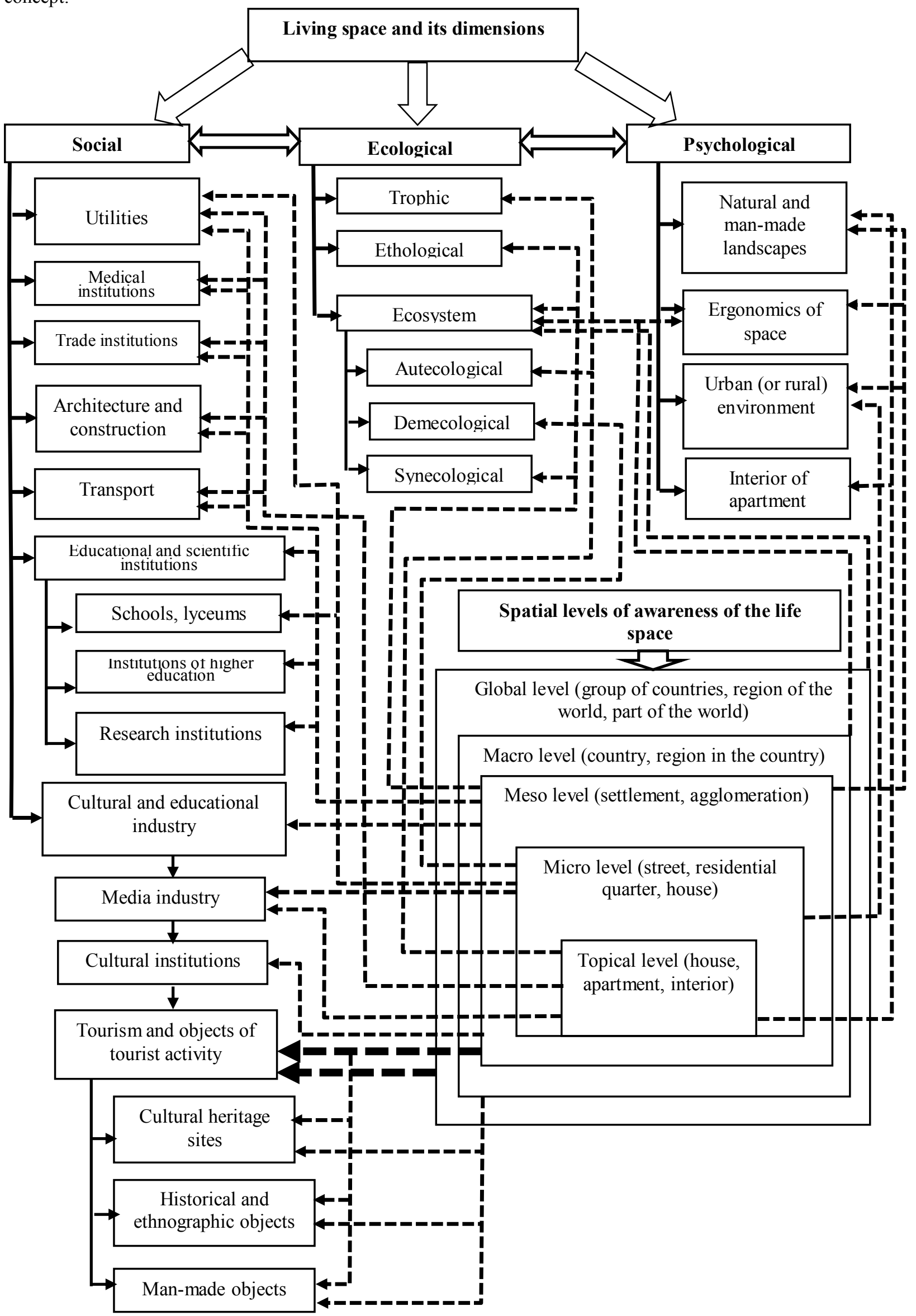

Fig. 1. Ontological scheme of the modern idea of the category "space of life". 
Today's ideas about the space of life are formed above all through the requirements of modern civilization for comfort, convenience, and psychological state of man living and working in complex and stressful conditions of the human community, which due to various technological and cultural achievements "fits" for the environment.

Let's analyze in details the individual dimensions of the category "living space" (Fig. 1). Above all, the authors are closest to the ecological dimension, which is based on fundamental ideas about the biosphere "as a holistic, uniquely organized and constructed material object, which arose about 4 billion years ago and in which there is a qualitatively special form of matter - the biosphere." [2].

Based on this, the category of "living space" is primarily ecological precisely because it is based on the phenomenon of life, which through the life of the human population is realized in connection with the environment (Fig. 1). We have considered natural ecosystems, significantly transformed by man urboecosystems, it is necessary to consider their scientific content.

There are many definitions of an ecosystem Tansley A. G. in [3], P. Duvigne in [4], Eugene Odum in [5].

There are also different understandings of ecosystem boundaries [6].

However, more or less complete scope of the concept of "ecosystem" should include the following characteristics:

- being a natural or man-made functional system of the whole set of living beings, interconnected by trophic and other connections, and a certain relatively homogeneous physical (terrestrial, soil or aquatic) environment, which interact with each other... ";

- thermodynamically opened, interconnected with neighboring ecosystems, relatively resistant to external disturbances, stable over time, in its natural state, selforganized and self-regulating, living, non-entropic system;

- any size system, the structure and level of organization of which provide its long-term self-maintenance, material and energy transformation and biotic cycle [7].

It is important to understand what levels of living things are involved in formation of ecosystems. According to M.A. Golubets, "the infinite diversity of living beings on the planet belongs to one basic, universal, relatively independent, stable and primary level of organization - the organismic."

The second main level of organization of living things is considered to be population. It is a universal, integral, territorial, temporal, dynamic, independent structural and functional system. It has all without exception the biotic properties of the species. The third level is the ecosystem. It is on it that complex materialenergy relations of man with the natural environment are formed, which, in fact, forms the basis of the category "space of life" (Fig. 1).

However, urban ecosystems, within which, the space of human life is formed, occupy a special place in the categorical apparatus of modern ecology. This is due to the fact that the development of urban ecosystems and urbanization in general in most urban scientists symbolizes the ability of human civilization to do in their lives without nature.

However, the deepening of urbanization creates a number of purely urban problems, including:

- extreme complication of transport problems;

- increase in price of engineering equipment;

- air pollution;

- distance of the population of large cities from nature;

- "suction" by large cities of productive forces from small and medium-sized cities [8].

In scientific works on the formation of urban ecosystems are dominated by either biologizing or sociologizing approaches. In the publications of urban planners, sociologists, futurists it is difficult to find the necessary information about the ecological specifics and impact of cities on the environment. In the ecological works of the city, along with terrestrial and aquatic, forest and agricultural ecosystems are characterized as ecological systems, and their main features are called material and energy metabolism, population dynamics, landscape transformation and more.

So, Y. Odum [5] considers the city as "a heterotrophic ecosystem that receives energy, food, fibrous materials, water and other substances from large areas outside it." To confirm this, the following indicators are given:

- the need for energy per square meter of the city is about $4000 \mathrm{kcal}$ per day, which is 70 times higher than the need for the same area of oyster cans;

- in order to feed a city with a population of 1 million inhabitants need about 0.8 million hectares of land;

- to water and wash the necessary catchment, which would give 7.6 billion liters of water;

- more than 80 million kcal per inhabitant per year, while its annual physiological needs are only 1 million kcal.

Classifying ecosystems by energy performance, Odum [5] classifies cities as "industrial-urban fueldriven ecosystems (fossil, organic, or nuclear)" and believes that they can be managed as functional ecosystems.

The general features of the city's ecosystem, according to modern ideas, can be summarized in several positions. Urban ecosystem is a spatially limited natural-technogenic system, a complex set of interconnected metabolism and energy of autonomous living organisms, abiotic elements, natural and manmade, forming an urban environment (space) of human life that meets its needs: biological, psychological, ethnic, labor, economic, social.

It consists of interconnected and interpenetrating subsystems (environments): quasi-natural (transformed geographical environment), landscape-architectural, socio-economic, socio-industrial [9]. The connection between them is so great that almost none of them can perform their functions separately, and at the same time the absence of one of the subsystems leads to the destruction of the ecosystem "City" as a whole (Fig. 1).

As you can see, the main system-forming factors (elements of the system) are man (he himself and all activities carried out within the urban area and the 
natural environment) (relief, geology, climate, water, etc.).

Thus, the urban ecosystem should be understood as a natural ecosystem in which during the evolutionary development of nature and society, the functions of social security associated with the removal of inert matter outside the body level of HomoSapiens were isolated and strengthened. At the same time, purposeful radical structural modification of the natural ecotope by man is obligatory. Ecological functions, such as participation in the food chains of ecosystems, have remained at the organismic level in the form of metabolism, but are provided not at the ecotope level, but at the level of ecological niche, which today covers the entire biosphere (Fig. 1).

All this determines the nature of a separate, relatively autonomous ecological system, which is based on the interaction of the social organism as a whole with the environment, which is undergoing changes on its part [10].

\section{Presenting main material}

Having determined the methodological guidelines of the category "living space", we justify the choice as objects of study of urban ecosystems of the cities of Kryvyi Rih and Uman. The main hypothesis of the study is the assumption that despite the significant differences between city-forming factors and mechanisms in the urban ecosystems of these cities, environmental and social factors play the same role in the formation of living space. To do this, we compare the main parameters that characterize the living space in these urban ecosystems (table 1). The principles of parameter selection were not accidental. The authors in the selection process were guided by the following requirements:

- commonality (and, consequently, the ability to compare) of the main characteristics;

- main spatial features (area, configuration, distance);

- natural and landscape environment;

- main ecological characteristics;

- saturation of the urban environment with objects of infrastructure, cultural, historical and industrial heritage.

The logical result of a comparative analysis of the selected parameters should be a general assessment of the quality of living space in urban ecosystems. It should be clarified that such an assessment is mostly subjective, despite the fact that we made it not only by analyzing the parameters listed in Table 1, but also by telephone surveys of the population of Uman and Kryvyi Rih. In accordance with the requirements of such surveys [11] we called up to 100 people in each city by random telephone numbers $(70 \%$ by cellular numbers and $30 \%$ by Ukrtelecom). The questions asked required only an unambiguous answer - "yes" or "no". The questionnaires contained the following questions:

1. Do you like the urban lifestyle?

2. Do you consider Kryvyi Rih / Uman a big city?
3. Do you consider the urban environment of your city dangerous to health?

4. Do you consider the urban environment of your city safe for life?

5. Do you consider the urban environment of your city comfortable to live in?

6. In your opinion, can Kryvyi Rih / Uman be considered an ecologically dangerous city?

7. Is buying food in your city a big problem for you personally?

8. Is it a big problem for you personally to cover distances by public transport in your city?

9. Do you consider your personal home comfortable to live in?

10. Do you feel irritated when you meet individual tourists or tourist groups on the streets of your city?

The overall score was summed up in the last column on a 5-point scale in the dimension: 0 points - low quality of living space; 5 points - high quality of living space.

Emphasizing once again that the general assessment is mostly subjective, the authors suggest that even such an assessment makes it possible to assess in general such an ambiguous and non-mathematical category as "living space".

Given the ambiguity and a certain amount of subjectivity in these estimates, we consider it necessary to interpret them from the standpoint of the main objectives of our study.

- "Population" - gives a general idea of the living environment, as it largely determines the intensity and pace of life. By many estimates [12], highly urbanized metropolises due to the high pace of life cause the same high stress of the urban environment.

- "Average population density" - an average interpretation of the previous indicator, aimed at a correct comparison of different size and population of cities. However, the indicator may have an independent value, as to some extent characterizes the contagiousness of the urban environment, which in the context of disease epidemics becomes of paramount importance [13].

- "Configuration type" - an indicator that is actively used in the theory of placement [14, 15], architecture and urban planning [16] and in addition to purely geometric properties determines the ergonomic characteristics of the urban environment. In addition to verbal estimates of the configuration, mathematical models of such estimates are known, in particular, the Boyce index [17]. In our case, the elongated configuration of the territory of the city of Kryvyi Rih is far from optimal, both from a geometric and ergonomic point of view. However, this configuration creates the preconditions for the autonomy of certain areas (inner-city areas).

- "Spatial levels of awareness of the space of life" - a purely geographical indicator that characterizes the selfpositioning of man in geographical space. In our case (Fig. 1) to the macro level (and below), inherent in both cities, in the city of Uman is added a global level through the annual pilgrimage of Hasids from around the world to the grave of his spiritual teacher - Tsadik Nachman. 
Table 1. Comparison of development parameters that form the living space of urban ecosystems of Kryvyi Rih and Uman.

\begin{tabular}{|c|c|c|c|c|c|c|}
\hline № & Parameters & \multicolumn{2}{|c|}{$\begin{array}{l}\text { Kryvyi Rih } \\
\end{array}$} & \multicolumn{2}{|c|}{ Uman } & $\sum_{\mathrm{Kr} . \mathrm{Rig}} / \sum_{\mathrm{Uman}}$ \\
\hline 1 & Number of population & \multicolumn{2}{|c|}{619,300 (January 1, 2020) } & \multicolumn{2}{|c|}{82603 (January 1, 2020) } & $2 / 4$ \\
\hline 2 & Average population density & \multicolumn{2}{|c|}{1440.2 people $/ \mathrm{km}^{2}$} & \multicolumn{2}{|c|}{2028.3 people $/ \mathrm{km}^{2}$} & $4 / 3$ \\
\hline 3 & Configuration type & \multicolumn{2}{|c|}{ Linear, elongated from south to north } & \multicolumn{2}{|c|}{ Compact, close to a car } & $2 / 4$ \\
\hline 4 & $\begin{array}{l}\text { Spatial levels of awareness of the } \\
\text { space of life }\end{array}$ & \multicolumn{2}{|c|}{$\begin{array}{l}\text { Macro level, meso level, macro level, } \\
\text { topical level }\end{array}$} & \multicolumn{2}{|c|}{$\begin{array}{l}\text { Global level, macro level, meso } \\
\text { level, macro level, top level }\end{array}$} & $4 / 5$ \\
\hline 5 & $\begin{array}{l}\text { The level of contagiousness of the } \\
\text { urban environment }\end{array}$ & \multicolumn{2}{|c|}{$\begin{array}{l}\text { Mostly average, due to the high } \\
\text { autonomy of certain areas of the city } \\
\text { and the reduced probability of } \\
\text { contacts }\end{array}$} & \multicolumn{2}{|c|}{$\begin{array}{l}\text { Mostly high due to the significant } \\
\text { compactness of the urban } \\
\text { environment and high probability } \\
\text { of contact. }\end{array}$} & $4 / 2$ \\
\hline 6 & $\begin{array}{l}\text { The main type of natural } \\
\text { landscape }\end{array}$ & \multicolumn{2}{|c|}{ Steppe and valley-river landscapes } & \multicolumn{2}{|c|}{$\begin{array}{l}\text { Forest-steppe, valley-river and } \\
\text { protected landscapes }\end{array}$} & $3 / 5$ \\
\hline 7 & $\begin{array}{l}\text { The main type of anthropogenic } \\
\text { landscape }\end{array}$ & \multicolumn{2}{|c|}{ Mining and settlement } & \multicolumn{2}{|c|}{ Settlement } & $3 / 4$ \\
\hline 8 & Intensity of trophic relations & \multicolumn{2}{|c|}{ High, due to the large population } & \multicolumn{2}{|c|}{$\begin{array}{l}\text { Average due to the possibility of } \\
\text { running a farm }\end{array}$} & $2 / 4$ \\
\hline 9 & $\begin{array}{l}\text { The degree of rupture of trophic } \\
\text { chains }\end{array}$ & \multicolumn{2}{|c|}{$\begin{array}{l}\text { Significant due to the long distances } \\
\text { to the natural landscape }\end{array}$} & \multicolumn{2}{|c|}{$\begin{array}{l}\text { Insignificant due to proximity to } \\
\text { natural landscapes }\end{array}$} & $2 / 4$ \\
\hline 10 & $\begin{array}{l}\text { The predominant town-planning } \\
\text { function }\end{array}$ & \multicolumn{2}{|c|}{ Industrial } & \multicolumn{2}{|c|}{ Administrative and tourist } & $2 / 4$ \\
\hline 11 & $\begin{array}{l}\text { Saturation of the urban } \\
\text { environment with natural and } \\
\text { man-made objects, including }\end{array}$ & \multicolumn{2}{|l|}{ High } & \multicolumn{2}{|l|}{ Insignificant } & \\
\hline \multicolumn{2}{|c|}{ - the predominant type of housing } & \multicolumn{2}{|c|}{ Communal, multi-storey } & \multicolumn{2}{|c|}{ Personal one-story } & $2 / 4$ \\
\hline \multicolumn{2}{|c|}{ - social infrastructure } & \multicolumn{2}{|c|}{ Well developed } & \multicolumn{2}{|c|}{ Insufficiently developed } & $4 / 2$ \\
\hline \multicolumn{2}{|c|}{ - Eco-network objects } & Insufficiently rep & ted & Presented in diff & nt types & $2 / 4$ \\
\hline$-\mathrm{cu}$ & ural and industrial heritage sites & Mostly industrial & tage & Mostly cultural & itage & $3 / 4$ \\
\hline 12 & $\begin{array}{l}\text { Overall estimation of living space } \\
\text { (according to the results of the } \\
\text { survey) }\end{array}$ & satis & & & & $3 / 4$ \\
\hline & Questions & $\begin{array}{c}\text { Number of } \\
\text { answers "yes" }\end{array}$ & $\begin{array}{c}\text { Number of } \\
\text { answers "no" }\end{array}$ & $\begin{array}{c}\text { Number of } \\
\text { answers "yes" }\end{array}$ & $\begin{array}{c}\text { Number of } \\
\text { answers "no" }\end{array}$ & $\sum \mathrm{Kr}$ Rig $/ \sum \mathrm{Uman}$ \\
\hline 1. D & you like the urban lifestyle? & 83 & 17 & 52 & 48 & $5 / 3$ \\
\hline $\begin{array}{l}2 . \mathrm{D} \\
\mathrm{abi}\end{array}$ & $\begin{array}{l}\text { you consider Kryvyi Rih / Uman } \\
\text { city? }\end{array}$ & 96 & 4 & 12 & 88 & $3 / 4$ \\
\hline & $\begin{array}{l}\text { you consider the urban } \\
\text { onment of your city dangerous to } \\
\text { h? }\end{array}$ & 68 & 32 & 23 & 77 & $4 / 2$ \\
\hline $\begin{array}{ll}4 . \mathrm{D} \\
\text { env }\end{array}$ & $\begin{array}{l}\text { you consider the urban } \\
\text { onment of your city safe for life? }\end{array}$ & 34 & 66 & 88 & 12 & $2 / 4$ \\
\hline $\begin{array}{l}5 . \mathrm{D} \\
\text { env } \\
\text { to } 1\end{array}$ & $\begin{array}{l}\text { you consider the urban } \\
\text { onment of your city comfortable } \\
\text { e in? }\end{array}$ & 52 & 48 & 67 & 33 & $3 / 4$ \\
\hline $\begin{array}{l}\text { 6. Ir } \\
\text { Um } \\
\text { dan }\end{array}$ & $\begin{array}{l}\text { your opinion, can Kryvyi Rih / } \\
\text { n be considered an ecologically } \\
\text { erous city? }\end{array}$ & 87 & 13 & 8 & 92 & $1 / 4$ \\
\hline $\begin{array}{l}\text { 7. Is } \\
\text { prol }\end{array}$ & $\begin{array}{l}\text { buying food in your city a big } \\
\text { lem for you personally? }\end{array}$ & 23 & 77 & 9 & 91 & $4 / 5$ \\
\hline & $\begin{array}{l}\text { it a big problem for you personally } \\
\text { ver distances by public transport } \\
\text { ur city? }\end{array}$ & 76 & 24 & 12 & 88 & $2 / 4$ \\
\hline $\begin{array}{ll}9 . \mathrm{D} \\
\text { con }\end{array}$ & $\begin{array}{l}\text { you consider your personal home } \\
\text { fortable to live in? }\end{array}$ & 43 & 57 & 67 & 33 & $3 / 4$ \\
\hline $\begin{array}{l}10 . \\
\text { mee } \\
\text { grol }\end{array}$ & $\begin{array}{l}\text { you feel irritated when you } \\
\text { individual tourists or tourist } \\
\text { ps on the streets of your city? }\end{array}$ & 24 & 76 & 33 & 67 & $3 / 3$ \\
\hline $\begin{array}{l}\text { Tot } \\
\text { indi }\end{array}$ & $\begin{array}{l}\text { 1 values of habitat quality } \\
\text { ators Kryvyi Rih / Uman }\end{array}$ & & & $\begin{array}{l}72 / 94 \\
\text { of } 110 \text { points) }\end{array}$ & & \\
\hline
\end{tabular}

According to [18] in this case, Ukraine exports tourist impressions thanks to this attraction in the city of Uman. From the standpoint of the priorities of the postindustrial economy [19] export of raw materials (iron ore Kryvbas) is considered less important.
- "Level of contagiousness of the urban environment" an indicator used in medical geography [20], and in human ecology [21] and characterizes the degree of probability and possible recurrence of physical contact between people. It was actively used by the Swedish 
geographer Thorsten Hegerstrand in developing the theory of the spread of innovations [22]. In our case, the more compact territory of the city of Uman and higher population density contribute to a higher level of contagiousness of the urban environment.- "The main type of natural landscape" - a geo-ecological indicator that determines the main direction of transformation of natural landscapes into man-made. In addition, its independent significance lies in the aesthetic perception of the environment by the individual. In particular, forest-steppe landscapes by M.D. Grodzinsky and G.I. Denisyk [23] due to their greater diversity (vegetation, relief, hydrography) carry a greater aesthetic load than the steppe.

- "Intensity of trophic relations" - a purely environmental indicator, projected on human life. Despite being in an urban environment, mostly detached from the natural landscape, man still can not completely exclude himself from the system of material and energy relations that have developed in natural ecosystems. According to Y. Odum [5] and M. A. Golubets [7] in urban ecosystems there is a certain proportion in the ratio of purely ecological (in our case trophic) functions, and social (Fig. 1). In our case, in large cities, "detached" by the artificial urban environment from natural landscapes, social functions far outweigh the ecological ones.

- "The degree of rupture of food chains" - a more detailed interpretation of the previous indicator. In our case, it means the presence of more intermediaries as analogues of trophic levels in the ecological pyramid. The ideal case is when the food comes directly from the producer to the consumer (plant - herbivore), or from the consumer of the second order (herbivore) to the consumer of the first order (predator). According to the important environmental law Lindeman [25] when moving from one trophic level to another, no more than $10 \%$ of energy is lost. In the urban environment, analogues of trophic levels can be elements of the food distribution system (wholesale and retail trade network, natural markets, subsidiary farms).

- "Predominant urban function" - the indicator does not require detailed comment, as the negative impact on the living space of any industrial functions compared to others is obvious.

- "Saturation of the urban environment with natural and man-made objects" - this indicator is a certain hybrid of ecological and social content of living space (Fig. 1)

- "the predominant type of housing" - according to [26] one-floor buildings and the location of the house against the background of unchanged natural landscape significantly improves human living space.

- "social infrastructure" - a large list of artificially created facilities that provide mostly social needs of people living in cities [27]. In our case, there is a direct relationship - the larger the city, the more numerous are the objects of social infrastructure.

- "Eco-network objects" - their presence either in the city (arboretum "Sofiyivka" of NASU), or near it (Kryvyi Rih Botanical Garden of NASU) is evidence of the remoteness or proximity of the urban ecosystem to natural analogues. In addition, from a scientific point of view, the objects of the ecological network can be reference sites, through the study of which the degree of transformation of natural ecosystems as a result of anthropogenic activity is determined.

- "objects of cultural and industrial heritage" - a meaningful list of anthropogenic objects that play a significant role in the aesthetic perception of living space. In our case, they are represented as objects of material culture, formed in the process of long-term mining and industrial development of Kryvbas, and objects of spiritual culture, formed in Uman region in different historical epochs (Trypillia culture, garden art, pilgrimage center).

- "General assessment of living space (according to the results of the survey)" - is an average assessment obtained from the mass survey of residents of Kryvyi Rih and Uman. Has the degree of objectivity inherent in such a survey [11].

- "Do you like the urban lifestyle?" - The answer to the question largely determines the preferences of city dwellers in relation to the actual urban living space.

- "Do you consider Kryvyi Rih / Uman a big city?" - a logical continuation of the previous question, however, the answer to which better allows to determine a person's self-assessment of belonging to the urban environment.

- "Do you consider the urban environment of your city dangerous for health?" - Probably the most pressing issue, especially against the background of the COVID19 epidemic.

- "Do you consider the urban environment of your city safe for life?" - a question, the answer to which characterizes not only the criminogenic situation, but also the quality of work of municipal utilities and transport services.

- "Do you consider the urban environment of your city comfortable to live in?" - the antithesis of the previous question, the answer to which makes more clear the psychological dimension of the category "space of life" (Fig. 1)

- "In your opinion, can Kryvyi Rih / Uman be considered an ecologically dangerous city?" - Given a certain populism in the use of the phrase "environmentally dangerous", most respondents quite clearly understand what is being said, as evidenced by the number of positive answers (83 "yes" for residents of Kryvyi Rih and 8 "yes" for residents of Uman).

- "Is buying food in your city a big problem for you personally?" - The question has an age imprint, as most of the negative answers came from Ukrtelecom's city numbers, which is mainly due to the lack of mobile phones or smartphones among the elderly.

- "Is it a big problem for you personally to cover distances by public transport in your city?" - The answer to this question helps to clearly trace the relationship between the optimal configuration of the city and the need to move it. As in the previous question, mostly elderly people gave positive answers (76 "yes" in Kryvyi Rih).

- "Do you consider your personal home comfortable to live in?" To a large extent, the positive answer to this question testifies to the reaction of city residents to the latest trends in the arrangement of personal housing (Fig. $1)$, which is impossible without the presence of such 
elements of urban infrastructure as construction supermarkets and construction and repair specialists.

- "When you meet individual tourists or tourist groups on the streets of your city, do you feel annoyed?"

Almost the same number of positive and negative answers (76/67, respectively) to the last question in our opinion indicates the special role of tourism in the formation of positive content of the category "living space" in the city of Kryvyi Rih and Uman. Probably, this is the branch of human activity that should "sew" all the different characteristics of the living space for its holistic positive perception.

The authors have some experience in the study of tourism [28]. Today, the living space of the cities of Kryvyi Rih and Uman can be enhanced by positive content precisely due to its use in tourism. To do this, the authors have developed appropriate tourist routes and guides.

Participation of objects of tourism and tourist activity in the formation and use of the living space of the city of Kryvyi Rih.

1. Transport tourist route "My Kryvyi Rih". Length $60 \mathrm{~km}$. Passes through the territory of the Metallurgical, Pokrovsky, Saksagansky areas of the city of Kryvyi Rih.

2. Transport tourist route "Journey to the world of plants (Kryvyi Rih Botanical Garden)". The length is 70 $\mathrm{km}$. It passes through the territory of Metallurgical, Saksagan, Pokrovsky, Ternivsky districts.

3. Transport tourist route "Kryvbas - geological". The length is $60 \mathrm{~km}$. It passes through the territory of the Central City, Saksagan and Pokrovsky districts.

4. Transport tourist route "They defended the Motherland". The length is $50 \mathrm{~km}$. It passes through the territory of the Central City, Saksagan and Terniv districts of the city of Kryvyi Rih.

5. Transport tourist route "Thorny roads of Kryvyi Rih". Length $15 \mathrm{~km}$. Passes through the territory of Metallurgical, Ingulets and Central City districts.

6. Transport tourist route "By the way of the liberated city". Length $4.1 \mathrm{~km}$. Passes the territory of Central City and Saksagan districts.

7. Transport tourist route "Remember the past - for the future". Length $30 \mathrm{~km}$. Passes through the territory of Ingulets district.

8. Transport tourist route "From Ingulets to Ingulets". Length $45 \mathrm{~km}$. Passes the territory of the Central City District.

9. Transport tourist route "Northern Gate of Kryvbas". Length $21 \mathrm{~km}$. Passes the territory of Terniv district.

10. Transport tourist route "Pokrovsky district - the pearl of Kryvyi Rih". Length $10 \mathrm{~km}$. Passes through the territory of Pokrovsky district.

11. Transport tourist route "Living River of Time". Length $19 \mathrm{~km}$. Passes through the territory of Pokrovsky and Saksagansky districts.

12. Transport tourist route "Cossack roads of Sicheslav region". Length $100 \mathrm{~km}$. Passes through the territory of Metallurgical, Central City, Ternivsky districts.
13. Transport tourist route "My native Kryvyi Rih". Length $30 \mathrm{~km}$. Passes through the territory of Metallurgical, Central City, Ternivsky districts.

14. Transport tourist route "Industrial Kryvbas". Length $30 \mathrm{~km}$. Passes through the territory of Metallurgical, Ternivsky, transit through the Pokrovsky area.

15. Transport tourist route "Kryvyi Rih - the industrial heart of Ukraine". Length $30 \mathrm{~km}$. Passes the territory of Ingulets and Metallurgical districts.

The analysis of these transport and transportpedestrian routes showed that the largest transport and tourist load is experienced by Metallurgical and Central City districts (7 routes each), Ternivsky, Pokrovsky, Saksagansky districts (6 routes each), the least - Ingulets district ( 3 routes). However, the elongated configuration of the city "provides" each of its inner-city districts with participation in the implementation of tourist activities.

Due to the elongated configuration of the city of Kryvyi Rih in previous publications in order to optimize tourist routes, the authors used the tool "Poligons of Thyssen-Voronoi" in GIS Mapinfo.Prof. (Fig. 2, 3) [28]. The authors plan to carry out a similar optimization in future research for the city of Uman.

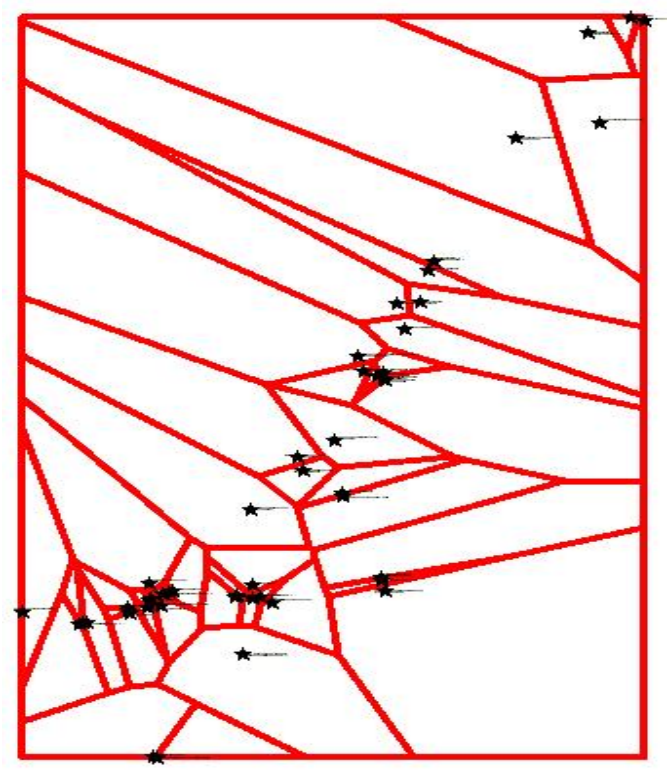

Fig. 2. General scheme of Voronoi polygons throughout the city of Kryvyi Rig.

The use of historical and cultural sites of the city of Uman in tourism and in the formation of the living space of the city.

The city of Uman is one of the oldest cities in Ukraine with a rich history, the chronicle of which is adorned with numerous bright historical events and prominent personalities.

The city is geographically located in the center of Ukraine since ancient times and today plays an important role as a highway. Cherkasy region is located in the heart of Ukraine. The public highway of state importance Kyiv-Odessa, M-05 passes through it. It is part of the European road route E-95 (St. Petersburg-Kiev-OdessaSamsun-Merzifon). This highway connects many 
prominent cities, among which the dominant position is occupied by Uman, Cherkasy region.

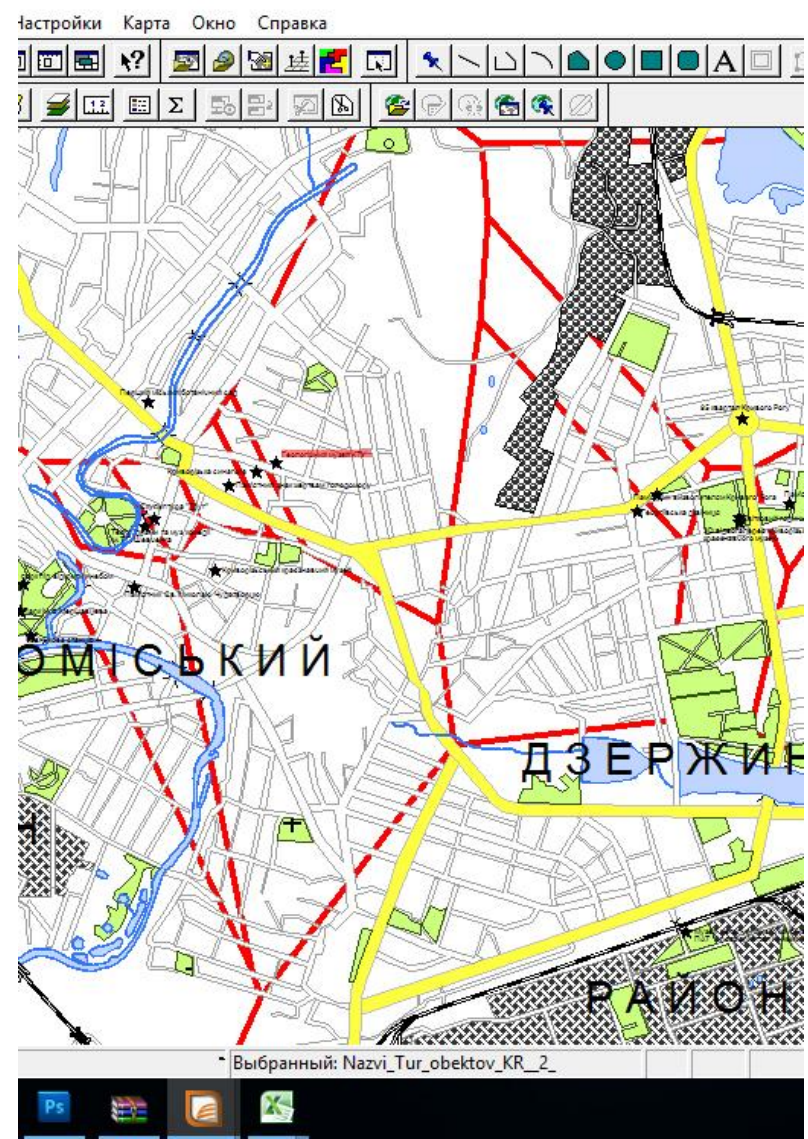

Fig. 3. Fragment of the scheme of Voronoi polygons in innercity areas with the highest density of tourist attractions.

The city is geographically located in the center of Ukraine since ancient times and today plays an important role as a highway. Cherkasy region is located in the heart of Ukraine. The public highway of state importance Kyiv-Odessa, M-05 passes through it. It is part of the European road route E-95 (St. Petersburg-Kiev-OdessaSamsun-Merzifon). This highway connects many prominent cities, among which the dominant position is occupied by Uman, Cherkasy region.

Uman is a city of regional subordination and the second most populous city in the region. The city has many historical and cultural sites (monuments) of world importance, which in turn needs special attention and support from the state. There are about 40 monuments, memorials and other memorials in the city.

The city is divided into the following neighborhoods: - Suburbs "Turok" - the oldest district of Uman with many architectural monuments. The Stara Uman State Historical and Architectural Reserve is located in the larger territory of the district.

- "Bald Mountain": an old area with one-story private estates.

- "Domansky": the smallest neighborhood in the east of the city with one-story private estates.

- "Babanske KP": an old area with one-story private estates in the south of the city with underdeveloped infrastructure.
- "Eastern": founded in the early 90's of last century. Streets parallel to the E-95 highway are named after the cities of the region (Cherkasy, Smilyanska, Shpolyanska, Korsun-Shevchenkivska and others), and between them Twin Cities. Streets perpendicular to the route - "East 1, East 2... East 12".

- "Zvenigorod suburb": this name is almost never used. Located in the central part of the city with old one-story private estates and height differences.

- "Ivangorod suburb": a quiet neighborhood above Ostashivsky pond, developing, has many high-rise buildings, shops and cafes.

- "Suburbs of Bessarabka": also called "sleeping area", is located in the southwest of the city with a large number of high-rise buildings and popularly known as "railway station area".

- "Mischanka": an area of private estates with developed infrastructure, located in the north-western part of the city.

- "Slobidka": lies in close proximity to the park "Sofiyivka" in the northern part of the city.

- "Nova Uman": is located in the northeastern part of the park "Sofiyivka" and is directly adjacent to the center of the Hasidic pilgrimage "Tomb of Tsadik Nakhman", there are both private estates and five-story buildings.

- "DOS": officers' houses in the northern part of the city. More than ten five-storey houses of old buildings, several nine-storey buildings were built at the end of the last century and two are still under construction.

In addition, the following names of the following districts are used in everyday life:

- "Zarembova dam": an area of private estates above "Zarembovymstav" in the southern part of the city with underdeveloped infrastructure.

- "Oleksiyivka": the most remote area in the northern part of the city, consisting of one street - Karmelyuka (№ 145-205). It is located near the "Oleksiyivsky" pond - the river Palanka.

- "GRES microdistrict": is one of the most remote from the center. Five-storey buildings were built in the middle of the last century for the workers of the greenhouse plant.

- "Center": a densely populated area with different types of houses, many shops and financial institutions. The best infrastructure and proximity to the center has determined the popularity of the area.

- "Proletarskaya": north-western part, sleeping area, more than ten five-storey panel type.

- "Tyshchyka": five-storey and nine-storey buildings, shops, bazaars and more.

- "Breeding": several three-story buildings and private estates in the immediate vicinity of the "breeding station" (Uman Research and Breeding Station). Located in the northeastern part at the entrance to the city.

- "Avtostrada" (Belogrudovskaya Street): is the most remote area from the city center in the north of Uman. There are more than ten five-story buildings, shops, a hospital and the Belogrudovsky forest nearby.

- "Greek Forest": the newest neighborhood of the city. The project was developed by Umanavtodor. It is planned to build five- and fifteen-storey residential buildings, shopping, office, entertainment, cultural and 
educational centers, a park area, and underground parking lots on the area of 22.9 hectares. That is, for the first time in the region it is planned to build a modern residential complex with a full infrastructure. The founders of the project plan to provide residents of the Grekiv Lis residential district with street lighting, playgrounds, round-the-clock water supply with multilevel water purification and filtration, digital telephone lines, dedicated Internet channel, silent high-speed elevators, security and video surveillance. The new complex is designed for 750 apartments, which can accommodate three thousand people from Uman.

In the city of Uman there are $178 \mathrm{~km}$ of roads, most of them with hard (asphalt) pavement; most intersections are equipped with traffic lights. Within the city there are 4 squares: Ivangorod Square, Gagarin Square, Victory Square and Sobornosti Square. The last new streets (about 20) were developed for the Vostok district in 1992. Every fifth square meter of housing in the region is being built in Uman

Longest streets:

- Stepana Banderi - 5.4 km;

- Energy - 3.6 km;

- Karmelyuk - 2.8 km;

- Kyiv - 2.5 km;

- International - $2.4 \mathrm{~km}$;

- Independence - $2.3 \mathrm{~km}$;

- European - $2.3 \mathrm{~km}$;

- Mykhailivska - 2.2 km;

- Assumption - $2.2 \mathrm{~km}$;

- Liberators - $1.8 \mathrm{~km}$;

- Factory - 1.7 km;

- Ivan Vyhovsky - 1.7 km.

Given that in the formation of tourist routes in most cases they are based on the world-famous attractions "Sofiyivka" and "Tomb of Tsadik Nakhman", adding other cultural and historical heritage sites can help in the formation of a higher quality of life.

\section{Conclusions}

1. The article defines the ontological affiliation of the category "life space", which is realized in the field of such basic sciences as sociology, ecology, psychology, geography.

2. The degree of influence of each of the dimensions of the category "space of life" on a person at different spatial levels is studied.

3. Various aspects of the use of living space in the urban ecosystems of Kryvyi Rih and Uman have been studied.

4. The role of the main branches of municipal economy which form and use a living space of the cities of Kryvyi Rih and Uman in particular in tourist activity is investigated.

\section{References}

1. Mitch Rose, The question of culture in cultural geography: Latent legacies and potential futures. Prog. Human Geography, (2020). DOI:https://doi.org/10.1177/0309132520950464
2. Igor K. Liseev, Ecology as a Way to Combine Knowledge about the Natural and Social in Human Being. Epistemol. Philos. Sci. 57 (4), 133-137 (2020). DOI: https://doi.org/10.5840/eps202057466

3. Laura J. Cameron, Sir Arthur Tansley. (2017). DOI: https://doi.org/10.1093/OBO/9780199830060-0094

4. S.M. Dombrovska, V.V. Kovregin, A.L. PomazaPonomarenko, O.M. Kolenov, Derzhavne upravlinnya u sferi bezpeky sotsial'noekolohoekonomichnykh system: monohrafiya (Public administration in the field of security of socioecological and economic systems: a monograph). (NUTSZU, Kharkiv, 2017), p. 244

5. N.V. Koneva, Ekologicheskiye imperativy v trudakh Gennadiya Rozenberga (Environmental imperatives in the works of Gennady Rosenberg). Samarskaya Luka: probl. regional glob. ecol. 28 (2), 127-151 (2019). DOI: https://doi.org/10.24411/2073-10352019-10219)

6. A. Klemmer, M. Loreau, Breaking Through Ecosystem Boundaries, Bull. Ecol. Soc. Am. 98, 9598 (2017). DOI: https://doi.org/10.1002/bes2.1313

7. Yu. Chernobay, Muzeyne vidobrazhennya koevolyutsiynykh metamorfoz seredovyshcha $i$ povedinky (Museum representation of coevolutionary metamorphosis of the environment and behavior). Proc. of the State Nat. Hist. Mus. 36, 3-14 (2020). DOI: https://doi.org/10.36885/nzdpm.2020.36.3-14

8. E.N. Pertsik, Geourbanistika: uchebnik dlya akademicheskogo bakalavriata (Geourbanistics: a textbook for an academic bachelor's degree). (Yurayt Publishing House, Moscow, 2018), p. 481

9. E.Sh. Akhmetova, Sotsial'no-institutsional'nyye usloviya sovershenstvovaniya ekosistemy kak sostavlyayushchey kachestvo zhizni naseleniya monopromyshlennogo goroda (Socio-institutional conditions for improving the ecosystem as a component of the quality of life of the population of a mono-industrial city) Abstract of a dissertation for the degree of candidate of sociological sciences. FSBEI HE "Penza State University" (2019), p. 22

10. Siân de Bell, H. Graham, Piran C.L. White, The role of managed natural spaces in connecting people with urban nature: a comparison of local user, researcher, and provider views. Urban Ecosyst. 21, 875-886 (2018). DOI: https://doi.org/10.1007/s11252-018-0762-x

11. M.G. Shapiro, Klassifikatsiya metodov oprosa v sotsiologii (Classification of survey methods in sociology) Social Research. 2, 51-59 (2017)

12. Richard Florida, Kryza urbanizmu. Chomu mista roblyat' nas neshchasnymy (The crisis of urbanism. Why cities make us unhappy). (Our format, Kyiv, 2019), p. 320

13. Ray M. Merrill, Introduction to Epidemiology (Jones \& Bartlett Learning, USA, 2015), p. 340 
14. L.E. Limonov, Regional'naya ekonomika $i$ prostranstvennoye razvitiye (Regional economy and spatial development). (Yurayt, Moscow, 2015), pp. 71-73

15. A.V. Kuznetsov, Sovremennyye teorii razmeshcheniya. Lektsiya dlya praktikantov geograficheskogo fakul'teta MGU im. Lomonosova (Modern placement theories. Lecture for trainees of the Faculty of Geography, Moscow State University Lomonosov). (INION RAS, Moscow, 2020), p. 39

16. M.A. Sokolova, K. Yu. Aleksandrova, Gorodskiye pustoty kak komponent gumanizatsii arkhitekturnoy sredy (Urban Voices as a Component of Architectural Environment Humanization). Archit. Modern Inform. Technol. 4 (49), 262-280 (2019). DOI: https://doi.org/10.24411/1998-4839-2019$\underline{00018}$

17. Andre Dauphine. Geographical Models with Mathematica (ISTE Press - Elsevier, 2017), p. 314

18. V.F. Kifyak, G.Yu. Bondarenko, Inozemnyy turyzm yak holovna skladova turystychnoyi diyal'nosti v prykordonnomu rehioni (Foreign tourism as the main component of tourist activity in the border region). Bullet. Chernivtsi Trade and Econ. Inst. 3 (67), 72-83 (2017)

19. O.V. Taranych, Osoblyvosti formuvannya konkurentnykh perevah rozvynenykh krayin na svitovomu rynku (Peculiarities of formation of competitive advantages of developed countries on the world market). Eco.org.manage. 3, 371-328, (2016)

20. D. Nikolaenko. Medical geography and infectious ecology of COVID-19 in the United States: approaches to a systematic GIS description. Environ. Epidem. J. 5, 1-18 (2020). DOI: https://doi.org/10.13140/RG.2.2.28685.97768.
21. I.A. Vasilenko, I.M. Trus, O.A. Pivovarov, L.A. Frolova, Ekolohiya lyudyny (Human ecology). (Accent PP, Dnipro, 2017), p. 183

22. D.Audretsch, M.P. Feldman, Knowledge Spillovers and the Geography of Innovation. Editors. Handbook of Urban and Regional Economics: Cities and Geography. 4, 2713-2739 (2004)

23. M.D. Grodzinsky, Landshaftna heohrafiya: stara nazva novoyi nauky chy vidrodzhennya mayzhe zabutoho? (Landscape Geography: The Old Name of a New Science or the Revival of the Almost Forgotten?). UGJ. 2, 59-64 (2017). DOI: https://doi.org/10.15407/ugz

24. G.I. Denisyk, K.V. Mezentsev, E.A. Antipova, A.G. Kizyun, Heohrafiya povsyakdennya: prostorove riznomanittya povsyakdennoho zhyttya (Geography of everyday life: spatial diversity of everyday life). Bulletin of Kharkiv National University named after V.N. Karazin, series "Geology. Geography. Ecology" 52, 63-70 (2015). DOI: https://doi.org/10.26565/2410-7360-2020-52-10

25. V. Khudoba, Y. Chikailo, Ecology (LDUFK, Lviv, 2016), p. 92

26. I.A. Saenko, L.R. Akhmetova, M.Yu. Belichenko, Izucheniye mneniya naseleniya o klassakh komfortnosti zhilykh domov (Study of the public opinion on the comfort classes of residential buildings). Young scientist. 10 (144), 88-92 (2017)

27. V.M. Novikov, N.M. Deeva, A.G. Gwelesiani, Sotsial'na infrastruktura na shlyakhakh reformuvannya mistsevoho samovryaduvannya (Social infrastructure on the way to local government reform). (Kyiv-Warsaw, 2018) p. 431

28. D. Shiyan, T. Kazakova, S. Sonko, Spatial organization of tourist attraction network of Kryvorizhzhia. J. Socio-Econ. Geog. 24 (1), 56-63 (2018). DOI: https://doi.org/10.26565/2076-13332018-24-06 